\title{
SVAKODNEVICA PRVIH MESECI OKUPACIJE 1941. U ČLANCIMA BEOGRADSKIH OPŠTINSKIH NOVINA
}

\begin{abstract}
APSTRAKT: Činjenica da Opštinske novine, kao istorijski izvor, u domaćoj istoriografiji nisu korišćene u dovoljnoj meri i da se oseća nedostatak radova na temu svakodnevnog života pod okupacijom, motivisala je autora da prikaže životne uslove u Beogradu kroz pisanje navedenih novina u hronološkim okvirima od 24. aprila, kada je izašao prvi, do 19. juna 1941. kada je zaplenjen poslednji broj.
\end{abstract}

Ključne reči: Novine, Drugi svetski rat, Srbija, Beograd, Beograđani, okupacija, svakodnevni život

U periodu od 1918. do 1941. Beograd je doživeo transformaciju iz varoši orijentalnog tipa u moderan grad koji je u mnogim aspektima modernizacije pratio ostale evropske prestonice. Prema poslednjem popisu stanovništva Kraljevine iz 1931, Beograd je imao 288.938 stanovnika, što ga je činilo najvećim gradom $\mathrm{u}$ zemlji. ${ }^{1} \mathrm{U}$ njemu je živelo i radilo oko 64.000 đaka, 9.000 studenata, 25.000 radnika. ${ }^{2}$ Beograd je sa preko 327 fabrika, u uslovima ekonomski nerazvijenog jugoslovenskog društva, bio među industrijskim centrima Kraljevine. ${ }^{3}$ Sa više od 170 osnovnih i srednjih škola, jednim univerzitetom, Srpskom kraljevskom akademijom, sedištem patrijarha Srpske pravoslavne crkve, 27 bioskopa, 8 profesionalnih i na desetine amaterskih pozorišta, 74 štamparije, predstavljao je kulturno-prosvetno i duhovno središte. Prema određenim merilima epitet moderno može poneti ono društvo u kome je preko $90 \%$ građana pismeno. Beograd je sa $86 \%$ pismenih stanovnika ne samo bio blizu navedene granice, nego je i u zemlji u kojoj je oko $45 \%$ stanovnika bilo nepismeno predstavljao oazu pismenosti. ${ }^{4}$ Ulična rasveta i kanalizacija, gradski prevoz, taksi služba, telefon i telegraf

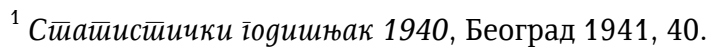

${ }^{2}$ Исто, 333-373.

${ }^{3}$ Исто, 182-183.

${ }^{4}$ Predrag J. Marković, Beograd i Evropa 1918-1941: Evropski uticaj na proces modernizacije Beograda, Beograd 1992, 41. 
samo su deo tekovina moderne tehnologije koje su bile na usluzi građanima ovoga grada. ${ }^{5}$ Podelom zemlje na banovine, 1929. i Uredbom o ustrojstvu i delokrugu rada Uprave grada Beograda, iz januara 1930, određeno je da opštine Beograda, Pančeva i Zemuna čine posebnu upravnu celinu pod nadzorom UGB-a. Na čelu UGB-a nalazio se upravnik, a njena funkcija bila je vršenje opšte-upravne vlasti i državne-policijske vlasti. ${ }^{6}$ Kao samoupravni organ, delovala je Opština grada Beograda. Njen operativni i administrativni deo, Glavno poglavarstvo Beograda, sastojao se od stručnih službi, odnosno odeljenja, odseka i referata, koji su izvršavali mnogobrojne poslove i obaveze na teritoriji Beograda.

Događaji koji su se odigrali u aprilu 1941. nasilno su prekinuli razvoj Beograda. Kao odgovor na puč i demonstracije od 27. marta, vođa Trećeg rajha Adolf Hitler naredio je napad na Jugoslaviju. Operacioni plan predviđao je da Beograd, kao „osinje gnezdo“, bude danonoćno bombardovan. Piloti Luftvafe poleteli su u noći između 5. i 6. aprila na izvršenje zadatka sa aerodroma u zapadnoj Rumuniji, Mađarskoj i Austriji. Prvi talas trajao je od 6.30 do 8.00 časova i u njemu su učestvovala 234 bombardera praćena lovačkim avionima. Pogođene su zgrade Glavnog generalštaba i Vojne akademije, Dvor na Dedinju i mnogi drugi objekti. Većinu Beograđana prvi talas je uhvatio na spavanju. Probuđeni detonacijama bombi, pokušali su da pronađu utočište u selima oko Beograda. Istog dana nacisti su bombardovali Beograd još tri puta. Piloti Šestog lovačkog puka, koji je bio zadužen za odbranu Beograda, iskazali su veliku hrabrost i uspeli da obore 18 nemačkih aviona, a za još 10 letelica se pretpostavlja da su pale usled dejstvovanja avijacije iznad Beograda. ${ }^{7}$

Grad je gađan još 7, 8. i 12. aprila, a ukupan efekat bombardovanja bio je poražavajući po njegove građane i infrastrukturu. U samo četiri dana, koliko je trajalo, od nemačkih bombi stradalo je više od 2.271 lica, a broj ranjenih bio je višestruko veći. Ukupno je oštećeno 9.365 zgrada (gotovo $50 \%$ celokupnog stambenog fonda) od kojih je 714 potpuno uništeno. Vodovodna i kanalizaciona mreža oštećena je na 360 mesta. Oštećenja je

\footnotetext{
${ }^{5}$ Исто, 135-151; Исйорија Беоїраgа, Београд 1974, 3, 115-153.

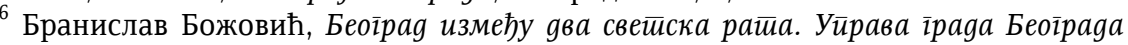
1918-1941, Београд 1995, 158-163.

${ }^{7}$ Polovina nemačkih gubitaka u borbi tokom Aprilskog rata nastala je na nebu iznad Beograda. Koliko je ovo bio veliki podvig pilota 6 . vazduhoplovnog puka možemo sagledati jedino ako ukažemo na činjenicu da su se borili protiv neprijatelja koji je na raspolaganju imao nekoliko puta veći broj aviona i čiji piloti su većinom bili letački asovi koji su do početka balkanske kampanje imali 10-25 pobeda. Više o dejstvovanju jugoslovenske avijacije u Aprilskom ratu: Bojan B. Dimitrijević, Milan Micevski, Predrag Miladinović, Kraljevsko vazduhoplovstvo 1918-1944, Beograd 2012, 443-483; Velimir Terzić, Slom Kraljevine Jugoslavije 1941, Beograd 1983, 404.
} 
pretrpeo i gradski prevoz, od 104 tramvajskih kola, koliko je Direkcija tramvaja i osvetljenja pre rata imala na raspolaganju, uništeno je 76, a od 87 gradskih autobusa uništeno je $48 .^{8}$

Kako je izgledao Beograd posmatran iz objektiva jednog od njegovih građana koji se u svoj grad vratio ubrzo posle bombardovanja saznajemo iz sledećih redova: „Kada sam izašao pred beogradsku stanicu, skoro nisam mogao da prepoznam okolinu kako je opustošena. Nije bilo uobičajene vreve i buke. Na izlazu nema nosača da nestrpljivo nude svoje usluge, a crni čistači cipela, što četkama klepeću po sanducima, da bi skrenuli pažnju na sebe, isčezli su sa uglova. Nije bilo užurbanih putnika, niti su ih automobili, prodornim piskom sirene, upozoravali, niti su se čuli tramvaji kako tandrču točkovima i razdražujuće škripe kočnicama. Nije bilo ni uličnih prodavaca da se nadvikuju, nudeći robu. Sa ruševina i zgarišta lak povetarac, s vremena na vreme, zapahnjuje mirisom čađi, negašenog kreča i tek iskopane ilovače." 9

Završetak Aprilskog rata za građane Beograda došao je 12. aprila kada je u polusrušeni grad ušla izviđačka grupa kapetana Klingenberga, sadržana od devet vojnika, pripadnika SS divizije Das Rajh (Das Reich). Invazione trupe koje su zauzele Beograd nisu uspostavile trajne organe za održavanje vlasti i svoje delovanje ograničili su na osiguranje ratnog plena, čuvanje zarobljenika itd. ${ }^{10}$ Do obrazovanja okupacione uprave u Srbiji pa samim tim i u Beogradu došlo je 22. aprila, o čemu nas obaveštava prvi broj Opštinskih novina ${ }^{11}$ od 24. aprila u kome se kaže: „General fon Ferster, kao vojni zapovednik Srbije preuzeo je izvršnu vlast.... Njima podređene vlasti su u Beogradu, Nišu i Skoplju feldkomandature, a u izvesnim drugim mestima ortskomandature. One imaju da čuvaju vojne interese nemačkih vlasti i da rukovode srpskim nadleštvima po gradovima i srezovima. “12

${ }^{8}$ Бомбарgовање Беоі̄раgа 1941-1944, Београд 1975, 23.

9 Војин Ђурашиновић Костја, Марӣовски и айрилски gани 1941. у Беоі̄раgу, Годишњак града Београда, VIII, Београд 1962, 432.

10 Muharem Kreso, Njemačka okupaciona uprava u Beogradu 1941-1944, Beograd $1979,67$.

${ }^{11}$ Opštinske novine izlazile su kao dnevni list od 24. aprila do 19. juna 1941. Glavni urednik bio je Aleksandar Stojković, profesionalni novinar, koji je u periodu 1936-1941. radio kao sekretar redakcije lista „Vreme“ i direktor novinske agencije „Evropa servis“ sa sedištem u Berlinu: Vojni arhiv (dalje: VA), Nedićeva arhiva (dalje: Nda), k. 58, f. 8, d. 1.

${ }^{12}$ Feldkomandatura 599 bila je oblasna komanda koja je na teritoriji Beograda vršila okupacionu vlast. Na njenom čelu nalazio se Ernst fon Kajzenberg (Ernst von Kaysenberg), a sastojala se iz komandnog štaba i upravne grupe. Na raspolaganje joj je stavljen ratni sud, vojni zatvor i jedan vod vojne policije. Sa razvojem okupacionog sistema, pri ovoj oblasnoj vojnoupravnoj komandi, formirani su Ured za kontrolu cena, ispostava Policije i Službe bezbednosti i postavljeni Opunomoćenik za privredu (Generalbevollmächtigte für Wirtschaft in Serbien), Referent za štampu i propagandu itd. Ubrzo je dobila i naziv Komanda grada Beograda (Stadtkommandantur Belgrade), a potčinjene su joj 834. i 838. krajskomandatura (Krei- 
U istom broju Beograđani su obavešteni „da nemačka vojska obezbeđuje potpunu ličnu bezbednost i život stanovništva“, ali i da će „nasilja i dela sabotaže biti najstrožije kažnjena".$^{13}$ Naređeno je da sva lica predaju „pribor za radio-emisije“, vatreno oružje kao i sva bojna sredstva. Spisak aktivnosti koje je sankcionisao Vojni sud bio je sledeći: neizvršavanje naredbe o predaji radio emisije i oružja, pomaganje lica koja nisu nemačka, a nalaze se u okupiranoj oblasti, „svako predavanje izveštaja licima ili vlastima van okupirane oblasti, koja nanosi štetu nemačkoj vojnoj sili i Rajhu“, „svako opštenje sa ratnim zarobljenicima“, „sakupljanje na ulicama, deljenje letaka, priređivanje javnih skupova i povorki“, te svaku drugu sličnu aktivnost koja nije prethodno odobrena od nemačkog komandanta ili koja je protiv nemačkog karaktera, „podstrekavanje na obustavu rada, zlonamernu obustavu rada, štrajk i zatvaranje preduzeća" itd. ${ }^{14}$ Uveden je i policijski čas koji je stupao na snagu u 19 časova, a prestajao u 5 časova ujutru. Posle jednog oružanog napada na nemačku patrolu postalo je jasno da 50. član Haške konvencije neće predstavljati prepreku za okupatora. Beograđani su upozoreni da će nemačka oružana sila u budućnosti na slične napade odgovoriti uzimanjem taoca i streljanjem istih. ${ }^{15}$

Okupator je donosio i mere kojima je težio da, u određenoj meri, normalizuje život u Beogradu. Naređeno je da sve „državne i opštinske vlasti, policija i škola“ nastave da rade jer će one "time služiti sopstvenom stanovništvu". Zanatske radnje, trgovine i banke morale su da nastave da pružaju usluge Beograđanima, svako „bezrazložno zatvaranje radnji“ bilo je zabranjeno. „Nagomilavanje robe za dnevnu upotrebu“ smatrano je sabotažom, a bez prethodnog odobrenja okupacionih vlasti bilo je zabranjeno „povećanje cena i smanjenje svake vrste nadnica koje su postojale na dan okupacije“.${ }^{16}$ Pored dinara, kao zvanična valuta, uvedena je i nemačka marka, a Beograđani su za 100 dinara mogli da dobiju 5 maraka. ${ }^{17}$

Usled teških oštećenja kanalizacione i vodovodne mreže, Opština grada je uputila naredbu Beograđanima da u roku od 24 sata u dvorištima,

skommandantur). - Оишӣинске новине, бр. 12, 24. април 1941, 1; M. Kreso, n. d., 87.

${ }^{13}$ Ойшйинске новине, бр. 12, 24. април 1941, 2.

${ }^{14}$ Исто.

${ }^{15}$ Ovaj član Haške konvencije garantovao je da „nikakva kolektivna, novčana ili druga kazna neće moći biti izdata protiv stanovnika zbog individualnih dela za koja oni ne bi mogli biti smatrani kao da su kolektivno odgovorni“ čime je ustanova taoca bila zabranjena.

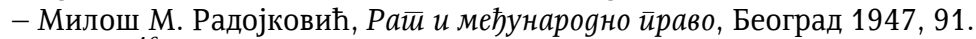

${ }^{16}$ Исто.

${ }^{17}$ Od juna 1941. do juna 1942. okupator i kolaboracionisti sprovode proces zamene ove valute za srpski dinar u odnosu 1:1. Nova valuta nije donela i monetarnu stabilnost jer je kolaboracionistički režim, usled nedostatka sredstava, praktikovao da štampa novac bez

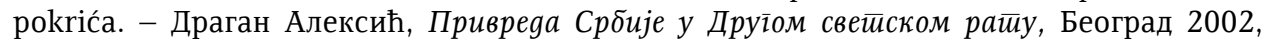
307-309. 
baštama i podrumima iskopaju „nužničke jame“ koje bi se posle trodnevne upotrebe zakopavale i dezinfikovale. Bilo je predviđeno da izvršenje naredbe nadgleda okupator, a najstrože je bila zabranjena upotreba „klozeta, koji su u vezi sa vodovodom... jer je vodovod oštećen i izmet će se razlivati po ulicama, i time naneti ogromnu opasnost od infekcije za građanstvo. ${ }^{18} \mathrm{Na}$ opasnost od pojave infektivnih bolesti ukazivali su i novinari Opštinskih novina koji su savetovali da Beograđani u cilju prevencije redovno peru ruke, te izbegavaju ljubljenje i rukovanje. Pojedini delovi grada i dalje su bili bez vode, apelovano je da se štedi i sakuplja kišnica koja bi se koristila za umivanje i kupanje. ${ }^{19}$

Jedan od glavnih problema za okupacione i kolaboracionističke organe od prvih dana okupacije bilo je obezbeđivanje i snabdevanje ishrane stanovništva u Beogradu. ${ }^{20}$ Opština je radi rešavanja ovog problema do 24 . aprila popisala sve pekare „koje nisu mnogo oštećene i koje se za rad mogu lako osposobiti“, a slobodne „hlebarske radnje“ dodeljene su „hlebarskim radnicima" kao i brašno od koga je bilo dozvoljeno da se peče „samo čist hleb, tj. bez ikakve mešavine s drugim brašnom“. ${ }^{21}$ Pokrenuta je i inicijativa da se za najsiromašnije otvore javne kuhinje, a da je ona na početku zloupotrebljena, svedoči podatak da su u prvoj kuhinji ovog tipa, koja se nalazila u Mladonagoričanskoj ulici, porciju mogli da dobiju samo opštinski službenici. Opštinske novine savetovale su stanovnike Beograda da se „umesto šeboja, lepe kate i perunike, dana i noći i drugog šarenog cveća, neguje krompir i šargarepa, pasulj, paradajz i salata. “22

Tih dana nije bilo bezbedno hodati po beogradskim ulicama. Vlasti nisu stigle da ograde sve neeksplodirane bombe. U najvećoj opasnosti bili su najmlađi Beograđani koji su se, kako prenose Opštinske novine, bezbrižno igrali „oko tih opasnih prostora, pa čak i pretrčavali preko nekog ispucalog i nabubrelog trotoara". ${ }^{23}$

Krajem aprila dolazi do uspostavljanja kolaboracionističkih policijskih vlasti u Beogradu. Za izvanrednog komesara za Beograd postavljen je jedan od predratnih šefova Odeljenja opšte policije UGB, Dragomir Dragi Jovanović. Na osnovu njegove Naredbe o ustrojstvu i delokrugu policije $\mathrm{u}$

${ }^{18}$ Ойшичинске новине, бр. 12, 24. април 1941, 2.

${ }^{19}$ Исто, 4.

${ }^{20}$ Minimalne zalihe hrane kod običnog stanovništva, razaranje u Aprilskom ratu, okupaciona podela zemlje koja je dovela do smanjenja privrednog zaleđa Beograda i rekvizicija, bili su glavni faktori koji su doveli do ovakvog stanja. Više o ovoj temi: Наташа Милићевић, О исхрани у окуйираном Беоїраgу 1941-1944, Токови историје, Београд 2012, 2, 77-91.

\footnotetext{
${ }^{21}$ Исто, 3.

${ }^{22}$ Исто, 4.

${ }^{23}$ Исто.
} 
Beogradu od 23. aprila uspostavljena je policijska vlast pod nazivom Policija-Beograd. ${ }^{24}$ Ovaj organ sa određenim izmenama preuzeo je delokrug rada i strukturu predratne UGB. Sastojao se od Administrativnog odeljenja, Odeljenja specijalne policije (predratna Opšta policija), Odeljenja krivične policije, Odseka za čuvanje morala, Centralne prijavnice, Finansijskog odseka, Odeljenja policijskih agenata, policijske straže i 7 kvartova (umesto predratnih 17). ${ }^{25}$

Napori okupatora i kolaboracionista da funkcionalno osposobe život u Beogradu u određenim segmentima davali su prve rezultate. Opštinske novine izveštavaju da je Beograd „opet počeo da dobija izgled velikog grada u kome se živi i radi“, da su „na mnogim mestima tramvajske pruge, zajedno sa električnim vodovima osposobljene za rad" i da su Beograđani „videli da se na nekim prugama tramvaji već kreću“. ${ }^{26}$ Prva tramvajska linija, koja je puštena u rad 26. aprila, saobraćala je na liniji br. 6 od Rasinske do Dvorske ulice. ${ }^{27}$ Kako navodi Nikola Besarabić, direktor Direkcije tramvaja i osvetljenja, do 25. aprila osvetljene su dobili stanovnici Topčiderskog brda, Senjaka, Gospodarske mehane i drugih krajeva. Tehnička direkcija izveštava građane 25. aprila da su vodu dobili stanovnici na Dedinju, Banovom brdu i Topčideru, a da su za Beograđane koji žive u ulici Miloša Velikog i Kralja Aleksandra postavljene javne česme. U ovom periodu popravljeni su i kolektori u mnogim ulicama, te se navodi da „Beograđani mogu da očekuju da se uskoro koriste kanalizacijom“. ${ }^{28}$ Određeni pomaci ostvareni su i u snabdevanju grada hranom. Iz okolnih sela na beogradske pijace pristizala su kola sa povrćem. „Zeleniš“ je dominirao na tezgama, a osećao se i dalje nedostatak putera, jaja, masti, svinjskog, živinskog i ribljeg mesa. $^{29}$

Bez obzira na sve pomake, životni uslovi u Beogradu i dalje su bili teški. U želji da suzbiju zarazne bolesti, opštinske vlasti savetovale su da se voda pre upotrebe prokuva 10 minuta, naređeno je „zaštitno pelcovanje celokupnog građanstva grada Beograda protiv tifusa i paratifusa“ i podsećano na „dužnost svakog građanina da svaki pojedinačni slučaj pojave zaraznih bolesti odmah prijavi kvartnom lekaru. “30 Mnogi građani i dalje nisu

${ }^{24}$ Бранислав Божовић, Беоі̄pag ӣog комесарском уйравом 1941, Београд 1998, 66.

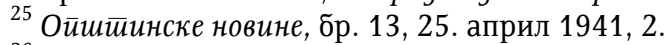

${ }^{26}$ Исто, 3.

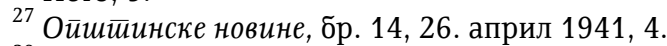

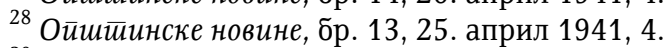

${ }^{29}$ Za vreme okupacije građani Beograda mogli su da se snabdevaju na sedam gradskih pijaca: u Gospodar Jovanovoj ulici, na Zelenom vencu, na Kalenićevom guvnu, Cvetnom trgu, Smederevskom đermu, u Bitoljskoj ulici „Palilulska“ i u Vidinskoj ulici „Bajlonova“. Н. Милићевић, н. p., 82.

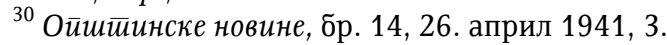


imali krov nad glavom zbog čega je obrazovan „odbor za smeštanje stanovnika bez stana" čiji članovi su obilazili sve rejone kako bi utvrdili tačan broj praznih stanova i kuća. Pojedini hoteli i škole rekvirirani su za potrebe smeštaja ovih ljudi koji su preko noći ostali bez svoje imovine. ${ }^{31}$

Nacisti su u Beogradu donosili i mere koje su izazivale dodatni nemir i strah u Beogradu i koje su pojedinim Beograđanima egzistencijalno ugrožavale život. Jedna od tih jeste i Naredba vojnog komandanta o kupovini životnih namirnica za Jevreje od 25. aprila, prema kojoj su pripadnici ove veroispovesti mogli da kupuju životne namirnice tek od 10:30 časova svaki dan, u redove za vodu i ostale namirnice mogli su da se uključe „tek pošto se ostali građani arijevci snabdeju“, a svim trgovcima bilo je strogo zabranjeno da im po višim cenama prodaju robu „ispod ruke“. ${ }^{32}$

Kako to zaključuje istoričar Kosta Nikolić, jedan od prioriteta okupacionih vlasti bilo je aktiviranjem kulturnog i zabavnog sadržaja sa ciljem da se "surovost okupacije na neki način relativizuje“. ${ }^{33}$ Opštinske novine od 27. aprila izveštavaju „Narodno pozorište počeće ponovo s predstavama $u$ prvoj polovini maja“, a prema izjavama Momira Veljkovića, tadašnjeg upravnika pozorišta, prvo će početi da se igraju „opere, a drama i balet ići će uporedo. ${ }^{\text {"34 }}$ Od kraja aprila, Beograđani su mogli da slušaju i Radio-Beograd (Sender Belgrad), na kome su emitovane vesti na nemačkom i srpskom jeziku, nemačke emisije i muzika. I bioskop „Beograd“ je otvorio vrata, ali su projekcije imali pravo da gledaju samo nemački vojnici. ${ }^{35}$ Ostali građani Beograda dobili su priliku da idu u bioskop od 6. maja, kada su otvoreni bioskopi „Novaković" i „Siti“, a na repertoaru su se našli „uglavnom avanturistički filmovi i melodrame, uz potpuno izbacivanje američkog filma. ${ }^{\text {" }} 6$ "Orač“, „Ginićc, „Šumatovac“, „Jugoslavija“ i „Skadarlija“ - bile su deo

${ }^{31}$ Исто.

${ }^{32}$ Navedene mere bile su samo uvod. Po izbijanju ustanka u Srbiji, okupator je, saglasno svojoj ideologiji čiji je važan segment bila teza da su Jevreji „uzrok svega zlog“, streljao internirane Jevreje, kao meru odmazde. U oktobru 1941, osnovan je logor na beogradskom Sajmu. Njegov zvanični naziv bio je logor Zemun (Konzentrationslager Semlin). Od 8. decembra 1941. do maja 1942, funkcionisao je kao Jevrejski logor Zemun (Judenlager Semlin). U ovom periodu u njemu je internirano ukupno oko 6.400 Jevreja i 600 Roma. Polovinom marta 1942, okupator je odlučio da sve zatočenike logora, Jevreje, većinom žene i decu, pogubi. Za ove potrebe u Beograd je, u aprilu, upućen specijalni kamion - pokretna gasna komora tzv. dušegupka, pomoću koga su nacisti, do 10. maja iste godine, sproveli „konačno rešenje“ u Srbiji, pogubivši oko 6.320 Jevreja. Više o ovoj temi: Milan Koljanin, Nemački logor na Beogradskom sajmištu 1941-1944, Beograd 1992.

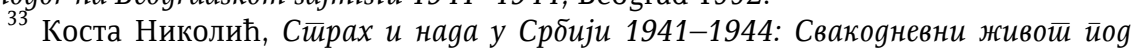
окуйацијом, Београд 2002, 148.

34 Више о раду београдских позоришта под окупацијом у: Василије Марковић,

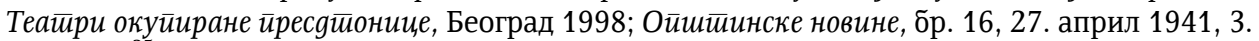

${ }^{35}$ Исто, 4.

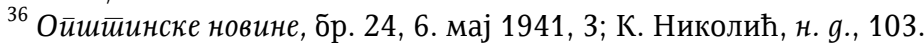


kultnih beogradskih kafana koje su obnovile rad. Prema izveštavanju Opštinskih novina „prvih dana posle rata publika je ručavala za stolovima bez belih čaršava i pila kuvanu vodu iz šolja za belu kafu“, ali uprkos oskudnoj ponudi i usluzi cene su bile „veće nego što bi trebalo da budu“. ${ }^{37}$

Uspostavljen je i železnički saobraćaj na glavnoj železničkoj stanici u Beogradu. Glavna zgrada bila je i dalje oštećena zbog čega su putnici bili primorani da karte kupuju u vozu. Opštinske novine od 29. aprila izveštavaju da vozovi „sasvim uredno odlaze i dolaze“ i da se 90 nosača prtljaga, od predratnih 220 , vratilo na svoja radna mesta. ${ }^{38}$ Do kraja aprila, većina zdravstvenih ustanova obnovila je rad. Beograđani su mogli da se obrate za zdravstvenu pomoć u rejonskim ambulantama, a na raspolaganju im je bilo i nekoliko bolnica, dispanzera i sanatorijuma. ${ }^{39}$

Usledile su nove naredbe okupatora. Na meti su se našli ponovo Jevreji. Šef grupe policije i službe bezbednosti naredio je: „Svi jevreji muškog pola, od 16 pa naviše imaju se javiti u sredu, 30-4. o. g. u 7, 30 časova bez obzira na njihovo dosadašnje određenje i oslobođenje." ${ }^{40}$ Od 28. aprila Jevrejima je bila zabranjena vožnja tramvajem, a upozoreni su i da će u slučaju da budu uhvaćeni na ulici bez žute trake biti strogo kažnjeni. Profesionalnim fotografima i ljubiteljima fotografije uskraćeno je fotografisanje i naređeno da se „već učinjeni snimci i filmovi“ predaju Opštini. ${ }^{41}$

Okupacione vlasti legalizovale su prostituciju u Beogradu. Bilo je predviđeno da sve osobe koje se bave „najstarijim zanatom“ dobiju „uredne knjižice za obavljanje takvog posla“. Prostitutke su morale da idu na lekarske preglede tri puta nedeljno, što je trebalo da smanji procenat veneričnih bolesti, koji je „prema dosadašnjem nalazu ogroman.“42

Tokom maja se u Beogradu osetila „velika nestašica hleba“. Ispred pekara je, i pre nego što je hleb bio ispečen, „čekalo po nekoliko stotina ljudi“. Na čekanje u redu bili su „osuđeni“ i pušači, trafike su ostale bez duvana, a u njima su se prodavali samo „stari primerci zabavnih listova“. ${ }^{43}$ Ciga-

${ }^{37}$ Ойшйинске новине, бр. 18, 29. април 1941, 3.

${ }^{38}$ Ойшиичнске новине, ор. 17, 28. април 1941, 3.

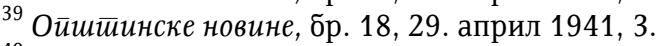

${ }^{40}$ Оишиичнске новине, бр. 17, 28. април 1941, 3.

${ }^{41}$ Ойшиичнске новине, бр. 18, 29. април 1941, 3.

${ }^{42}$ Potrebno je naglasiti da je prostitucija, ali i ostali oblici „intimnih odnosa“ sa okupatorom tokom Drugog svetskog rata u većini okupiranih zemalja Evrope bila široko rasprostranjena pojava. Ovaj vid "saradnje“ sa okupatorom u istoriografiji dobio je posle rata i poseban termin „horizontalna kolaboracija“. Prema istraživanju istoričarke Ljubinke Škodrić „horizontalna kolaboracija“ u Srbiji „nije imala razmere sličnih pojava u porobljenim zemljama Zapadne Evrope, ali nije bila ni zanemarljiva." Više o ovoj temi: Ljubinka Škodrić, "Horizontalna kolaboracija" - Intimne veze žena sa nemačkim okupatorom u Srbiji 1941-1944, Istorija 20. veka, Beograd 2013/1, 105-123; Ойшйинске новине, бр. 20, 2. мај 1941, 3.

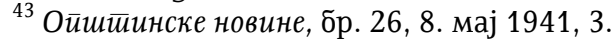


rete su se prodavale nelegalno u kafanama na komad, po ceni od jedan dinar. ${ }^{44} \mathrm{U}$ želji da se stanje promeni, okupator i kolaboracionisti su doneli niz mera. Izdata je naredba 4. maja „o maksimiranim cenama namirnica koje se ne smeju prekoračivati.“ Bilo je zabranjeno prodavanje „hleba, mesa, masti, butera, mleka, sira i jaja nemačkim vojnicima." Novine su svakodnevno informisale građane da su „pohapšeni neki prodavci životnih namirnica, koji se nisu pridržavali ovog cenovnika“. Opštinske vlasti donele su odluku da „otvore svoje prodavnice hrane „naročito hleba“, koje će prodavati robu po znatno nižim cenama od ostalih trgovina. ${ }^{45}$ Uprkos merama, cene su rasle nekontrolisano, a došlo je i do pojave crne berze. O ovim i sličnim malverzacijama Opštinske novine pišu „da se na beogradskim pijacama sve prodaje skuplje nego što to određuju cene“, „da su cene po kafanama i restoranima ne samo veće nego što to propisuje cenovnik nego su i količine koje se izdaju gostima znatno manje“, "da sopstvenici drvara skrivaju drva“, "da sopstvenici prevoznih sredstava i dalje bezobzirno ucenjuju građane tražeći za jednu vožnju po više stotina dinara" itd. ${ }^{46}$

Početkom maja obnovili su rad sudovi i tužilaštvo u Beogradu. Kasacioni sud počeo je sa radom 1. maja, Okružni i Beogradski apelacioni sud narednog dana, Sreski sud za Beograd ponovo je počeo da radi 7. maja, a podatak o obnovi rada Upravnog suda za Beograd nije naveden. ${ }^{47}$

I u maju je nastavljeno sa popravkama infrastrukture. Broj od 7. maja izveštava Beograđane da je vodovodna i kanalizaciona mreža popravljena na 22 glavna dovoda i da su na 48 mesta izvršeni „potrebni radovi na oštećenim uličnim cevima". Vozači motornih vozila, fijakeristi, taljigaši i ostali učesnici saobraćaja u Beogradu od 7. maja mogli su da saobraćaju u još 37 ulica, u koje su beogradski putari ugradili „160 kvadratnih metara obične kaldrme na kolovozu, 650 metara moderne kaldrme i 270 metara kolovoznog ivičnjaka. “48 Pozvano je svo osoblje Ministarstva za poštu i telegraf da se javi na dužnost, a na predlog komesara ovog ministarstva „vojne vlasti dozvolile su otvaranje telefonskog saobraćaja u Beogradu“ čime su se stvorili preduslovi „za življi rad privrednom svetu i snabdevanju životnim namirnicama građanstva u Beogradu“. ${ }^{49}$ Nisu svi Beograđani mogli ponovo da telefoniraju prema naredbi okupacionih vlasti: „Jevreji više ne mogu biti sopstvenici telefona $u$ Beogradu i oni su potpuno isključeni od davanja telefonske veze u Beogradu“. ${ }^{50}$

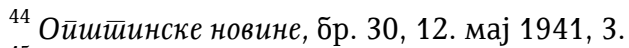

${ }^{45}$ Оишиичнске новине, бр. 22, 4. мај 1941, 3.

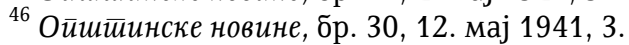

${ }^{47}$ Оишиичнске новине, бр. 24, 6. мај 1941, 3.

${ }^{48}$ Оишиичинске новине, бр. 25, 7. мај 1941, 3.

${ }^{49}$ Оишитинске новине, ор. 27, 9. мај 1941, 3.

${ }^{50}$ Исто.
} 
Početkom maja dolazi i do reorganizacije kolaboracionističkih vlasti u gradu. Odlukom novoobrazovane komesarske uprave od 7. maja obnovljen je rad UGB-a, a za upravnika je postavljen Dragi Jovanović. Karijera ovog kolaboracionističkog funkcionera dobija novu epizodu već 8. maja kada mu je povereno i mesto predsednika Opštine grada Beograda. „Prvi čovek“ Beograda obratio se svojim sugrađanima rečima: „Danas kada preuzimam u svoje ruke vodstvo opštine grada Beograda, ja imam pred sobom samo jedan cilj, da energičnim, nesebičnim i poštenim radom, vratim građanima Beograda, tako potreban duševni mir i uputimo Beograd putu punog prosperiteta... Ishrana, staranje o socijalnom i zdravstvenom pomaganju, uklanjanje tragova patnji beogradskog stanovništva, rad i samo rad, pošteni, nesebični, to je ona služba kojom ćete poslužiti najbolje našoj zajedničkoj kući, našem Beogradu. To je moja želja i zapovest. Ko tako ne misli i neće tako da radi, neka odmah ode. Da posle ne bi bilo dockan. “51

Komesar Ministarstva prosvete naredio je 9. maja „da svi đaci četvrtog razreda na području I gradskog školskog nadzorništva u Beogradu treba da pođu u školu 9 o. m. (maja - R. R.)“, a ubrzo je ista naredba važila i za đake ostalih nadzorništva. ${ }^{52}$ Pred beogradske prosvetare stavljen je težak zadatak, a glavni problem u organizaciji nastave bio je smeštaj đaka. Jedan deo zgrada oštećen je u bombardovanju i rekviriran za potrebe okupatora, čime su prosvetne vlasti bile primorane da đake šalju u škole koje su imale svoje zgrade. ${ }^{53}$

Broj od 15. maja donosi vest da je „na prvoj sednici Srpskog loptačkog saveza, rešeno da otpočne sportska aktivnost". Doneta je odluka da se organizuju utakmice za „Kup Srpskog loptačkog saveza“, a bilo je predviđeno da u ovom takmičenju učestvuje šest klubova od čega četiri iz Beograda (BSK, Jugoslavija, Jedinstvo i Bask). Propozicije takmičenja bile su uređene „po dvostrukom bod sistemu t. j. svaki klub će igrati utakmicu sa svakim i revanš", a prva utakmica bila je zakazana za 25 . maj. ${ }^{54}$

${ }^{51}$ Исто.
${ }^{52}$ Исто.

${ }^{53}$ Prema istraživanju Miodraga Simića, 14 srednjih i 12 osnovnih škola nije obnovilo rad. Sama nastava, u periodu od maja do juna, bila je neredovna. - Миодраг Симић, Школе у Беоїраgy у време окуйаuије og 1941. go 1944, Годишњак града Београда, XXI, Београд 1974, 75-89.

${ }^{54}$ Istoričar Dejan Zec ističe da je obnavljanje sportskog života u Srbiji bilo u sklopu težnji okupatora „da stvari u Srbiji što pre dođu u normalu kako bi okupirana teritorija što pre bila uključena u nemački odbrambeno-privredni sistem“. Prva fudbalska utakmica u okupiranom Beogradu odigrana je između kluba „Čukarički“ i ekipe nemačkog vojnog garnizona, u kojoj je, za razliku od „utakmice" u Aprilskom ratu, pobedu odneo domaći tim. -

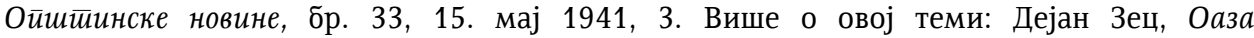

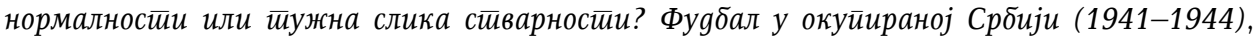
Годишњак за друштвену историју, Београд 2011, XVIII, 3, 49-70. 
U istom broju Beograđani su obavešteni da će na teritoriji njihovog grada sprovesti popis stanovništva i upozoreni da će svi koji na bilo koji način budu sabotirali ovaj proces dobiti novčanu ili zatvorsku kaznu. Doneta je i naredba o bezmesnim danima prema kojoj je svakog četvrtka i petka bila zabranjena "prodaja živog ili zaklanog svežeg mesa, sem živine i ribe. “55 Upravnik grada primetio je „da se po beogradskim kafanama, krčmama i bifeima upotrebljava alkoholno piće u tolikoj meri i na taj način da se usled njegove prekomerne upotrebe, ne samo remeti red i mir, već i građani time dolaze u položaj da sebi i svojim porodicama nanose štetu" što ga je navelo da donese Naredbu o točenju alkoholnih pića. Prema naredbi bilo je predviđeno da kafedžije „toče“ pivo i vino „u količini kojom se ne može dovesti u pitanje red i mir", „da alkoholna pića rakiju, rum i druge derivate mogu prodavati građanima samo u vremenu od 10 do 14 časova“. Za one koji prekrše naredbu predviđala se kazna i do 30 dana zatvora. ${ }^{56}$

Svoje kapije otvorio je 18. maja i Zoološki vrt, a koje životinje su Beograđani mogli da vide saznajemo iz sledećeg dela teksta: „Medveda, lavova i tigrova nema više u vrtu. Sve te opasne zveri iz predostrožnosti, morale su na dan bombardovanja biti poubijane. Neke životinje nastradale su pod ruševinama ili su uginule zbog neredovne ishrane za vreme rata. Ali najveći broj životinja ipak je ostao. Tu su i one najskupocenije slon i žirafe. “57

Pojedini Beograđani rešili su da konfuzno ratno vreme iskoriste kako bi protivzakonito pribavili materijalna dobra, a kojim metodama su se koristili saznajemo iz sledećih redova: „Građanstvo je više puta obaveštavano, da ne podleže raznim varalicama koji u ime opštinskih vlasti idu po kućama i isplaćuju račune za vodu, osvetljenje i t. d. obmanjujući građanstvo izdavanjem priznanica za isplaćene račune." Kako bi sprečila ove „varalice" Opština je obavestila građane da nije ovlastila nijedno lice da naplaćuje račune i da se isti mogu platiti preko Poštanske štedionice. ${ }^{58}$

Broj od 19. maja donosi reportažu sa stadiona fudbalskog kluba „Jugoslavija“ gde je odigrana utakmica između Jugoslavije i BSK, kojoj je prema proceni reportera prisustvovalo „pet do šest hiljada ljudi većinom starih predratnih navijača." Interesovanje za fudbalsku igru su pokazali i pojedini nemački vojnici „koji su zauzeli mesto na tribinama i s velikim interesovanjem pratili tok ove prve letnje borbe „crvenih" $\mathrm{i}$ „plavih“." "59

Redovna rubrika u Opštinskim novinama bila je i „Kažnjeni spekulanti i besposličari" koja je izveštavala građane o hapšenju i kažnjavanju

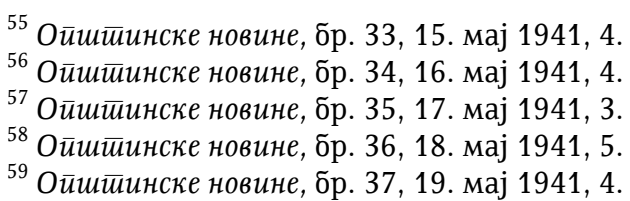


lica zbog „spekulacije“, besposličarenja, kockanja i tome slično. Iz njih saznajemo da su Beograđani koji su se bavili navedenim „mutnim“ poslovima i ukoliko su uhvaćeni od strane policijskih organa bili u opasnosti da provedu od 10 do 30 dana u zatvoru. ${ }^{60}$ Pored zatvorske kazne, okupacione vlasti nisu se ustezale da zbog određenih prekršaja i streljaju. O ovome svedoči sledeće obaveštenje Vojnog komandanta: „Beogradski stanovnik A. S. H ... zbog pljačke je od strane Ratnog suda komande osuđen na smrt. Presuda je danas izvršena (20. maja - R. R.). Ovaj slučaj se stavlja na znanje celokupnom stanovništvu u Beogradu, radi upozorenja." ${ }^{\text {"61 }}$

U drugoj polovini maja opštinske vlasti privodile su kraju popravku infrastrukture. Kako izveštavaju Opštinske novine, „U Beogradu čiji je vodovod za vreme bombardovanja bio vrlo oštećen, sada ima još vrlo malo ulica bez vode. Vodovod je svuda proradio i do vode nije teško doći." ${ }^{\prime 2}$ Ukinute su terenske jedinice koje su raznosile vodu po Beogradu. I vakcinisanje protiv tifusa privodilo se kraju, o čemu svedoči podatak da je do 22. maja u Beogradu vakcinisano 130.000 osoba.

Novinari Opštinskih novina bavili su se ponovo 23. maja pitanjem nabavke hleba: „Proja je jedini hleb koji se poslednjih nekoliko dana može dobiti u beogradskim pekarama. Mada su bili navikli na pšenični hleb, Beograđani su se ovog puta obradovali kada su videli da ima dovoljno proje i da ispred hlebarnica ne mora više da se čeka na red, kao što je bio kada se prodavao pšenični hleb." ${ }^{63}$ O kvalitetu ovog pekarskog proizvoda ostalo je zabeleženo sledeće: „Retka je pekara u Beogradu u kojoj se može dobiti dobra proja. Skoro svuda ona je slabo, odnosno rđavo pečena, puna vode, gnjetava. Ako stoji dan-dva ona postaje gorka i više se ne može jesti." ${ }^{64}$ Prema Opštinskim novinama znatno bolja situacija bila je na pijačnim tezgama dobro snabdevenim zelenom salatom, lukom, rotkvicama, trešnjama, jabukama i ostalim voćem i povrćem. Konstatovano je da mesa ima u dovoljnim količinama, ali i da nedostaje svinjskog i goveđeg. ${ }^{65}$

Po prirodi stvari većina Beograđana na okupatora nije gledala blagonaklono, a kojim metodama su se pojedini koristili kako bi izrazili svoj stav saznajemo iz sledeće objave nemačkih vlasti: „Od strane nemačke oružane sile sve češće su žalbe da civilno stanovništvo u odnosu sa nemačkim oficirima i vojnicima ne pokazuje njima dužnu pažnju i poštovanje. Naročito se sve više primećuje da jedan veliki deo stanovništva u pešačkom sao-

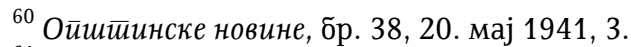

${ }^{61}$ ойшйинске новине, ор. 39, 21. мај 1941, 4.

${ }^{62}$ Исто.

${ }^{63}$ ойшичинске новине, ор. 41, 23. мај 1941, 4.

${ }^{64}$ Исто.

${ }^{65}$ Исто.
} 
braćaju ne pokazuje nimalo sklonosti da se ukloni nego često na drzak način preprečava put. Krajskomandatura upozorava stanovništvo da će se ubuduće protiv istupa ove vrste postupiti sa svom strogošću. “66

Građani Beograda su 29. maja proslavljali svoju gradsku slavu Spasovdan, a s obzirom na okolnosti savetovano je da se proslava „ne sme odlikovati količinom jela i pića, niti sjajem spoljašnjim“ i da „učešće celog Beograda treba da bude u mislima, u srcu i u duhu. ${ }^{~}{ }^{67} \mathrm{Za}$ razliku od radnji koje su na ovaj dan bile otvorene samo do podne, ugostiteljski objekti radili su puno radno vreme. O samom činu proslave zabeleženo je: „Svoju slavu Spasovdan proslavila je beogradska opština ove godine skromno. Sečenje kolača obavljeno je u sali Gradskog poglavarstva. Pored činovništva i službenika prisustvovao je i veliki broj beogradskih građana."68

Jedna od omiljenih aktivnosti Beograđana $u$ predratnom periodu bilo je kupanje na gradskim plažama, a da Beograđani ni leta te 1941. godine neće odustati od ove zabave nagoveštavao je sledeći članak Opštinskih novina: „Na Savskoj plaži uveliko je počelo kupanje. Za sada su otvorena samo kupatila „Smiljevo“ i kupatila „Bob-kluba“. Za koji dan počeće s radom i opštinsko kupatilo." 69

Kako je vreme odmicalo kulturno-zabavna ponuda prestonice bila je sve raznovrsnija. Građani Beograda su u prvim junskim danima mogli da, $\mathrm{u}$ Umetničkom pozorištu na Kolarčevom univerzitetu, pogledaju predstavu „Žene u pozadini“ ili baletsku predstavu „Lepi Dunav“. Za ljubitelje sedme umetnosti održavane su projekcije filmova u 11 bioskopa poput "Sinovi brda“, „Žena kao ti“, „Slepi miš“ itd. ${ }^{70}$ Oni sportskog duha su 8. juna mogli da uživaju u nastavku "lakoatletičarskog takmičenja na stadionu BSK-a", a pored srpskih atletičara u ovoj priredbi učestvovali su i „nemački vojnici, među kojima se nalazi i Vajnkec rekorder i nemački prvak u skoku u vis“. Podne je bilo rezervisano za fudbal, a bilo je predviđeno da „između poluvremena prve utakmice beogradski biciklistički podmladak vozi pet krugova." 71

Opštinske novine su na pravoslavni praznik Duhovi izdale trobroj za 8, 9. i 10. jun. U njemu su sumirani rezultati „napora“ okupatora i kolaboracionista $u$ normalizaciji prosvetnih prilika u gradu. U članku se između ostalog tvrdi: „U Beogradu ima 35 državnih i privatnih narodnih škola, sa 553 odeljenja i 20.152 đaka ukupno. Rad je obnovljen 12. maja i sada se nastava izvodi u 154 odeljenja. Školu ukupno pohađa 5.083 đaka." Isti broj

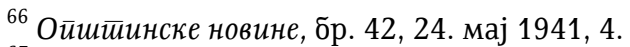

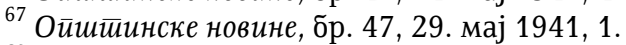

${ }^{68}$ Ойшиинске новине, бр. 48, 30. мај 1941, 3.

${ }^{69}$ Оишиичнске новине, бр. 50, 1. јун 1941, 3.

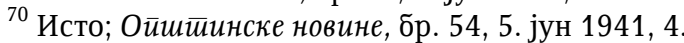

${ }^{71}$ Ойшиичнске новине, бр. 57, 8, 9, 10. јун 1941, 5.
} 
obaveštava Beograđane da je sa radom otpočela i Gradska biblioteka, čije je radno vreme bilo od 8 časova ujutru do 8 časova uveče. ${ }^{72}$

$\mathrm{Ni}$ u junu nije došlo do stabilizacije tržišta hrane, a novinari Opštinskih novina su krivce pronašli u poljoprivrednicima: „Nadležna vlast treba da jednom za svagda prekine to ordinarno pljačkanje Beograđana, od strane seljaka, koji nedonošenjem jaja i mleka na pijace grada ne samo ugrožavaju snabdevanje građanstva životnim namirnicama, nego još i sabotiraju naređenja nemačkih vlasti. “73 I u broju od 13. juna nastavljeno je sa rubrikom „Pljačkanje beogradskog stanovništva“. Ovaj put na „tapetu“ su bili „beogradski trafikanti koji u ovim teškim prilikama iskorišćuju momenat, da bi na račun sirotinje povećali zaradu“ i „umesto da cigarete prodaju direktno potrošačima, oni ih prodaju kelnerima za $20 \%$ do $30 \%$ skuplje. ${ }^{" 74}$

$\mathrm{U}$ istom broju analiziran je i rad javnih kuhinja. Do navedenog datuma na teritoriji UGB-a radilo je 5 javnih kuhinja. U toku maja „izdato je u ovim opštinskim kuhinjama 34.340 obroka“, a „za prvih 10 dana meseca juna izdato je 36.755 obroka tople hrane ${ }^{\text {“75 }}$ Prema istoimenom izvoru $\mathrm{u}$ kuhinjama Opštine se „ishranjuje 1.801 porodica sa oko 5.000 članova“, na šta je dnevno odlazilo 30.000 dinara. $^{76}$

Novinari Opštinskih novina nisu se ustezali da zbog loše snabdevenosti Beograda osnovnim životnim namirnicama napadnu i okupacione i kolaboracionističke vlasti. O ovome svedoče članci u brojevima od 16. i 17. juna. U članku „Aprilska šala“ od 16. juna kritikuju se novinari Novog vremena zbog toga što donose „uz slike na kojima se vide pune korpe najfinijeg voća i povrća, mlekarice sa velikim kantama mleka itd., gotovo svakodnevno članke o izobilju na pijacama" što je bilo u potpunoj suprotnosti sa faktičkim stanjem na beogradskim pijacama. ${ }^{77} \mathrm{U}$ broju od 17. juna u članku pod naslovom „Nepravda i zločin“, između ostalog, navodi se: „Sva obećanja o novom redu i pravičnosti ostala su samo na papiru. A možda su bila potrebna da zavaraju nas mali sitan, radni svet da bi oni velike, parajlije, imali vremena da nam ispred nosa razgrabe ono malo zaliha što se pojavilo na pijacama i bakalnicama. “78

Na početku rada ukazali smo da je okupator u Beogradu uspostavio oštar režim i zbog toga ne treba da nas čudi što je posle ovakvog načina izveštavanja broj od 19. juna zaplenjen. Posle ovog datuma Opštinske novi-

\footnotetext{
${ }^{72}$ Исто, 4.

${ }^{73}$ Оичитинске новине, ор. 58, 11. јун 1941, 5.

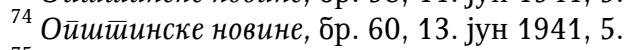

${ }^{75}$ Исто.

${ }^{76}$ Исто.

${ }^{77}$ Оичиичнске новине, ор. 63, 16. јун 1941, 3.

${ }^{78}$ Оишиичнске новине, бр. 64, 17. јун 1941, 3.
} 
ne, kao dnevni list zadužen da daje najvažnije informacije Beograđanima, nisu više izlazile. ${ }^{79}$

Opšte je mesto $u$ istoriografiji da novine, kao izvor, gotovo uvek prenose zvaničan stav vlasti. Nema sumnje da se taj stav u izvesnoj meri ocrtava i u člancima Opštinskih novina, ali uprkos ovoj činjenici mišljenja smo da se iz pisanja novinara lista može steći dobar uvid u svakodnevni život Beograđana u prvim mesecima okupacije. U kratkim crtama bio je to život u gradu, teško stradalom od bombardovanja, u koji je ušao okupator, zaveo strog režim pod kojim je pojedinim Beograđanima „osporeno“ pravo na život, u kome je čekanje u redu i nedostatak osnovnih životnih namirnica bila svakodnevna pojava, ali i u kome je, uprkos svim problemima, postojala mogućnost da se ode $u$ pozorište, bioskop, zoološki vrt, na plažu itd. Tako je u Beogradu oblikovan novi vid svakodnevice, koja se u mnogim segmentima razlikovala od one u mirnodopskom periodu i koja će uz određene izmene biti na "snazi“ do okončanja okupacije.

${ }^{79}$ Opštinske novine obnovile su rad 1942. kao nedeljni list, a od 1943. izlaze jednom mesečno. U ovom periodu one su bile službeni organ Gradskog poglavarstva grada Beograda tj. forma i funkcija im je bila slična Službenim novinama: VA, Nda, k. 58, f. 8, d. 1. 
Rade Ristanović

EVERYDAY LIFE IN THE OCCUPIED BELGRADE 1941 IN THE ARTICLES OF THE MUNICIPALITY NEWSPAPERS

\section{Summary}

Municipality Newspapers, as historical source, in our historiography are not being used enough, so the impression of lack of literary works subjected to daily life under occupation are the facts that motivated the author to try to analyze daily life of Belgrade citizens in accordance with the newspaper's content in chronological frame from April $24^{\text {th }}$ when the first number was issued until Jun $19^{\text {th }}$ when the last number was confiscated. Newspapers, as a source, almost always reflects official stance of the authorities, so there is no doubt the stance is reflected on articles of the Municipality Newspapers, but despite this fact, we support the possibility of making the review regarding daily life of Belgrade citizens in the first months after the occupation started through the writings of newspaper's journalists. Shortly, it was a life in the occupied city affected by bombing operation under the Nazi regime which ideology oppugned to some citizens the right to life, the city in which waiting in a line and lack of basic rations was everyday event, but also the city which, despite all problems it faced, offered going to theatre or to the beach etc. Listed factors formed one new picture of daily life in Belgrade, which was different in many aspects from the one from period of peace, so the one which is going to be in power until the end of occupation. 